DOI 10.18551/rjoas.2021-11.22

\title{
EVALUATION OF INTERNAL CONTROL SYSTEM OF INVENTORY CYCLE IN ANIMAL FEED COMPANY: A CASE STUDY AT PT. PANGLIMA PRIMADONA GEMILANG / PPG SURABAYA
}

\author{
Intan W. Jenifer* \\ Master's Program in Accounting, Faculty of Business and Economics, University of Mataram, \\ Indonesia
}

Husnan Lalu Hamdani, Rifa'i H. Ahmad, Lecturers

Faculty of Business and Economics, University of Mataram, Indonesia

*E-mail: jennifer.intan@yahoo.com

\begin{abstract}
This study aims to determine how and whether the inventory cycle internal control system applied to PT. PPG Surabaya has been running effectively. The research method used is a qualitative method. Data collection techniques are observation, interview, documentation and literature study. The results of the research conducted indicate that the inventory cycle internal control system applied at PT. PPG Surabaya has not been implemented effectively and in accordance with COSO and CSA standards which consist of five elements of the internal control system, namely the control environment, risk assessment, control activities, information and communication as well as supervision and monitoring. The advice that can be given is that the control system should be carried out not only manually, but also must be supported by the use of existing technology applications.
\end{abstract}

\section{KEY WORDS}

Inventory cycle, internal control system.

Today, economic growth is moving very rapidly marked by the emergence of so many local, national and multinational companies. This causes very fierce and tight competition between one company and another. That is, every company, especially a manufacturing company, must have high quality products at competitive prices. In other words, manufacturing companies are required to have a good internal control system so as to create effectiveness and efficiency that is beneficial for the company's survival in the future.

Committee of Sponsoring Organization (COSO) in Moeller (2009:32) provides a definition of internal control as follows: Internal control is a process, affected by an entity's board of directors, management, and other personnel, designed to provide reasonable assurance regarding the achievement of objectives in the following categories:

a. Effectiveness and efficiency of operations;

b. Reliability of financial reporting;

c. Compliance with applicable laws and regulations.

Internal control is influenced or implemented by all employees, both directors and employees at the lowest level in a company. With good internal control, the company can be said to have effectiveness and efficiency in operations, has reliable financial reports and ensures that the company complies with applicable laws and regulations. An internal control is closely related to the control self assessment (CSA). Moeller $(2009: 253)$ says that:

CSA is a process designed to help departments within an enterprise assess and then evaluate their internal controls. In many respects, the CSA approach uses some of the same concepts found in the COSO internal controls framework. The CSA model says that an enterprise must implement strong control objectives and control activities in order to have an effective control environment. These two elements are surrounded by a good system of information and communication as well as processes for risk assessments to monitor performance. 
CSA is a process for assessing and evaluating a company's internal control. In some respects the CSA approach uses some of the same concepts as the COSO internal control framework. The CSA model explains that companies must implement strong control objectives and control activities in order to have an effective control environment. These two elements are surrounded by sound information systems and communities and processes for risk assessment to monitor performance.

This CSA concept combines internal evaluators with operational managers for each activity to form a work team which is usually facilitated by internal evaluators. The team will assess and evaluate the company's risk management. CSA and inventory cycle internal control evaluation have something in common, namely reviewing and evaluating the effectiveness of an activity within the company. Thus, the evaluation of the inventory cycle internal control more or less refers to the CSA concept.

CSA and inventory cycle internal control evaluation is an effective tool for evaluating the internal control of a company or organization. This internal control refers to the effectiveness and efficiency of an organization or company. According to Daft (2006:12), "effectiveness is the extent to which the organization achieves predetermined goals. And efficiency refers to the amount of resources used to achieve goals." Meanwhile, according to Bayangkara (2008:13), "efficiency is a measure of the process that connects inputs and outputs in company operations". Effectiveness and efficiency are very important in a company. These two things become a measure of the success of a company.

The effectiveness and efficiency of a company can be achieved with the cooperation of all employees in all operational functions of the company, especially the production function. Inventory management has a very important role in a manufacturing company. This is because the production function is a major milestone in a manufacturing company. Samuelson and Nordhaus (2005:109) say that "the production function specifies the maximum output that can be produced with a given quantity of inputs". So that inventory management determines the number of existing inputs to produce the maximum amount of output. So, an effective and efficient production function is one of the keys to the success of a company because it can provide a number of advantages or greater profits for the company.

The company's profit is the main key or as an indicator that the company can be said to be good and able to maintain the continuity of the company. Increasing company profits will depend on the extent to which resources are used effectively, efficiently and economically. Companies need to evaluate and assess the effectiveness and efficiency of the company's operations, in the aspect of internal control of the inventory cycle. From the initial interview with the owner of the company, it was found that the company's development was felt to be stagnant and profits were not increasing. Based on initial observations also found several problems that occur in the internal control system, especially in the inventory cycle at PT. PPG. The problems that occur in PT. The first PPG is the absence of clear access control in the warehouse, unclear access control, namely warehouse access that can be accessed by anyone, as a result existing inventory can be lost without being noticed. The second problem is that PT. PPG does not use stock cards in recording existing inventory, as a result there is a lot of fraud in the inventory cycle so that there can be errors in the inventory counting process that can harm the company.

The third problem is that there is no segregation of duties in the warehouse, as a result, in the recording process and in the expenditure of warehouse inventory, it is carried out by one person so that fraud can occur such as manipulation of incoming and outgoing inventories. The fourth problem is the absence of a clear receipt of goods documents, as a result the owner cannot know what goods are received, as a result the risk of remaining inventory can be sent again by the supplier so that the inventory in the warehouse becomes piled up.

The implementation of the evaluation of the internal control of the inventory cycle in the company is very important which is aimed at evaluating and assessing the effectiveness and efficiency of the internal control system in the company's production function. With the 
evaluation of the inventory cycle internal control will have an impact on profit development for the survival of the company. including:

Based on this, in this study there are several things that the author wants to examine,

- How is the implementation of the internal control system at PT. PPG, and is the implementation of this system, especially in the inventory cycle, in accordance with the production function standards set by company management?

\section{LITERATURE REVIEW}

Etymologically, the word system actually comes from the Greek language, namely "systema" which in English is known as "system". According to various literatures, the system has a sense of a set of parts or components that are interconnected on a regular basis and constitute an inseparable whole.

According to Herman (2012: 6) the system is a device (or unity) which consists of components that are organized according to the sequence and according to their duties in order to achieve certain goals or missions.

According to Tata Sutabri (2004:6) the system is a collection of related resources to achieve certain goals. Furthermore, according to Mulyadi (2008:2) the system is basically a group of elements that are closely related to one another, which function together to achieve certain goals.

Internal control is an activity that is very important in achieving business goals. Likewise, the business world has increased attention to internal control. Internal control is all organizational plans, methods, and measurements chosen by a business activity to secure its assets, check the accuracy and reliability of the business's accounting data, improve operational efficiency, and support compliance with established managerial policies (Anastasia \& Lilis, 2010: 82). The internal control system consists of policies and procedures designed to provide reasonable assurance to management that the company has achieved its goals and objectives (Hery, 2011:87).

Objectives of Internal Control According to Arens et al (2008, p.370), the internal control system consists of policies and procedures designed to provide management with reasonable assurance that the company has achieved its goals and objectives. These policies and procedures are often referred to as controls, and collectively make up the entity's internal control.

In the research that the researcher conducts, the purpose of internal control that will be examined and emphasized is its relation to efficiency and effectiveness. According to the Big Indonesian Dictionary, Efficiency is (1) the accuracy of the way (effort, work) in doing something (by not wasting time, effort, cost); usability; efficiency, (2) the ability to carry out tasks properly and appropriately (without wasting time, effort, cost).

According to Arens (2008, p.375) Internal Control - Integrated Framework issued by the Committee of Supporting Organization (COSO), which is the most widely accepted control framework in the United States, outlines five components of internal control that are designed to be implemented. by management to provide reasonable assurance that its control objectives will be achieved. Each component contains many controls, but the auditor focuses only on controls designed to prevent or detect errors and fraud. COSO's internal control components include the following:

1. Control Environment Consists of actions, policies, and procedures that reflect the attitude of top management, directors, and owners of the entity as a whole regarding internal control and its importance to the entity;

2. Risk Assessment An action taken by management to identify and analyze relevant risks in the preparation of financial statements in accordance with GAAP;

3. Control Activities There are actually many control activities of this kind in any entity, including manual and automated controls Control activities are generally divided into five types, as follows: a. Adequate segregation of duties, b. Appropriate authorization of 
transactions and activities, c. Adequate documents and records, d. Physical control over assets and records, and e. Independent performance check;

4. Information and Communication (Information and Communication);

5. Monitoring activity relates to the continuous or periodic quality assessment of internal control by management to determine that the control is operating as expected, and has been modified in accordance with changing conditions. This assessed information comes from a variety of sources, including studies of existing internal controls, internal auditor reports, exception reporting on control activities, and feedback from operational personnel.

Every company, both industrial companies, trading companies and service companies must have inventory. Inventory is very important for trading and manufacturing companies. Inventory is needed to create sales, and sales are needed to generate profits. inventory affects the balance sheet in the income statement. In the company's balance sheet, inventory is a very vital current asset.

Trading companies whose activities are buying and selling finished goods, have inventory in the form of finished goods or merchandise. Meanwhile, manufacturing companies that have to process raw materials into finished goods have three types of inventory, namely raw material inventory, work-in-process inventory, and finished goods inventory.

Inventories of merchandise for industrial companies are different from inventories for trading companies. This is because the daily activities of these two types of companies are different. In general, the term merchandise inventory is used to indicate goods held for resale or used to produce goods for sale.

Although conceptually different but still have the same goal, here are some definitions of inventory according to experts:

According to Indonesian Accounting Standards (IAI) in PSAK No. 14 (2009) declared inventory were: 1 . Available for sale in the normal course of business, 2 . In the process of production and or in transit, or 3 . In the form of supplier equipment for use in the production process or providing services.

According to Kieso and Weygandt (2008: 402) Inventory is asset items held for sale in normal business operations or goods that will be used or consumed in producing goods to be sold. The benchmark for the progress of manufacturing companies can be seen from the activity of using raw materials for production. The bigger the company, the bigger the raw materials that will be used. The effectiveness of the use of raw materials in the company is determined by the size of the management supervision of the raw materials themselves. The effectiveness of measuring the use of raw materials is not easy, it takes a quality, quality and directed performance. In addition, a careful understanding of the raw material itself is required.

One of the bases for estimating the use of raw materials during a certain period, especially during the ordering period is the average use of raw materials in the previous period. This needs to be considered because the estimates of the use of raw materials are the spearhead in controlling the raw materials themselves. Handling of raw materials needs to be directed so that their use is right on target.

Control of raw materials is achieved through functional arrangements, assignment of responsibilities and documentary evidence. It starts from the approval of sales and production budgets by finalizing products that are ready to be sold and shipped to warehouses or customers.

The purpose of controlling raw materials according to James A. Hall (2001: 21) in his book accounting information systems: "The purpose of controlling raw materials is to plan and control the company's raw materials, a manufacturing company must have raw materials on hand to meet the needs of raw materials and keep must avoid excessive levels of raw materials".

This research refers to two previous studies, namely:

1. Francis (2017). The design of this research is a case study at PT Wijaya Prima Baja Indonesia which is a manufacturing company engaged in steel. The problem that occurs is 
the internal control system that is directly related to the supply of raw materials in the company. The type of data used in this study is qualitative and the methods used are interviews, observation, and documentation. The result of this research is PT Wijaya Baja Indonesia has good internal control in its inventory cycle. This is evidenced by the following 5 COSO frameworks applied to inventory activities:

- The control environment has been well implemented in every area, especially in the warehouse area of PT. Wijaya Prima Baja Indonesia with the support of the 5R program;

- Risk assessment applied to PT. Wijaya Prima Baja Indonesia has done well by showing existing internal controls such as stock taking;

- Control activities of PT. Wijaya Prima Baja Indonesia has implemented segregation of duties, authorization of transactions and activities, documentation and records, physical control over assets and records very well;

- Information and communication have used adequate documents in each inventory procedure so that all have been properly recorded and reported;

- Supervision at PT. Wijaya Prima Baja has been running well and in accordance with existing policies, this can be seen from the organizational structure and job-desk.

2. Hans (2017). This study compiles an internship report using a descriptive method where the internal will explain the internal control of raw material inventory that runs within the company. This study aims to describe the process of internal control of raw material inventory at PT Gawih Jaya. The research design used is an exploratory research that does not hypothesize. This study will describe descriptively about the cycle and internal control of inventory that runs within the company and evaluate it based on the COSO framework. The types and sources of data used are qualitative data. Data collection tools and methods used are observation, interviews, and documentation. The results of this study are PT. Gawih Jaya already has proper internal control on the inventory cycle. This is evidenced by the existence of 5 COSO frameworks that are applied to all activities related to inventory. The five COSO frameworks that have been running well are: 1 . A control environment that is not only created but also implemented well by every human being of PT. Galih Jaya. 2. Risk assessment which shows that PT. Galih Jaya has minimized risk by implementing existing internal controls. 3. Control activities of PT.Galih Jaya which has implemented 6 categories of physical control in its entire inventory cycle. This is also supported by the use of SAP software which has a very adequate control function. 4. Information and communication PT. Gawih Jaya has used adequate documents for each inventory procedure so that all activities can be recorded, recorded and reported properly because of the SAP software. 5. Supervision of PT. Gawih Jaya which has been going well because it is in accordance with existing policies.

3. Henmaidi and Heryseptemberiza in "Evaluation and Policy Determination of Raw Material Supply of Pasted Type Cement Bags at PT. Semen Padang". The object of research in this research is about inventory, Economic Order Quantity, Periodic Order Quantity, Simulation. This study concludes that this study still does not take stockout into account. In terms of inventory investment, the management of bagged materials is not optimal when compared to other countries. Deterministically, it is found that the inventory policy that is close to optimal for extensible kraft paper is the inventory policy with the POQ method.

4. Another research by Eko Priyanto in "The Feasibility of Using the Economic Order Quantit y (EOQ) Method To Achieve Fuel Inventory Efficiency At PT. Kereta Api (Persero) DAOP IV Semarang " which concluded that the EOQ method helps companies in placing orders to achieve company efficiency compared to using conventional inventory methods.

5. Then Harahap and Indra (2008) analyzed planning and monitoring of merchandise inventory using the EOQ method in their journal entitled "Analysis of Planning and Monitoring of Merchandise Inventory with the Economical Order Quantity (EOQ) Method at PT Fastfood Indonesia Medan Branch". The results showed that by using the EOQ method, the cost of ordering Pepsi cola at PT Fastfood Inodnesia Medan Branch in 2008 could be saved Rp $7,071.00$ compared to using the company's calculation method. 
6. Hari Prasetyo, Hafidh Munawir, Ning Ati Musthfiyah in their research on Inventory Model Development by Considering Material Expiration Time and Incremental Discount Facts. This study concludes and considers the material expiration time and the incremental discount factor to get the minimum total cost of inventory. The single item Economic Order Quantity (EOQ) inventory model is used as the basis for model development. A model solution search algorithm is created to obtain a solution from the model. In addition, at the end, a case study of the implementation of the model at PT.XYZ is given.

7. Furthermore, Slamet Nugroho in his research "Controlling the Inventory of Raw Materials for Underwear Using the EOQ Method at CV. Fajar Bahagia Klaten. In this study concluded that the company's policy regarding the purchase of raw materials is not optimal. According to company policy the Total Cost of Inventory (TIC) is Rp 1,818,088.5 while the Total Cost of Inventory (TIC) according to the EOQ method is amounting to $\mathrm{Rp}$. $1,621,698.89$, so there is a difference of Rp. 196,389.61. To anticipate things that are not desirable related to the supply of raw materials such as: delays in the arrival of orders for raw materials, the company must provide a safety stock of $997,61 \mathrm{~kg}$. According to the EOQ method the company must perform "You can reorder" (Re-Order Point) when supplies are only $1,400.44 \mathrm{~kg}$.

Based on several previous studies, it can be concluded:

1. The similarities of previous studies number 1 and 2 with this study are that they both carried out qualitative research using COSO analysis, while the difference was in the object of research and additional analysis with CSA in this study.

2. While research numbers 3 to 7 have similarities regarding research in inventory control, while the difference is that previous studies used a quantitative approach while this study used a qualitative approach.

\section{METHODS OF RESEARCH}

This research is an applied research. According to Sekaran and Bougie (2009:5-6) provide an explanation that, one is to solve a current problem faced by the manager in the work setting, demanding a timely solution. For example, a particular product may not be selling well and the manager might want to find the reason for this in order to take corrective action. Such research is called applied research. In sum, research done with the intention of applying the results of the findings to solve specific problems currently being experienced in an organization is called applied research.

This research was conducted using a case study method which was defined by Sekaran and Bougie (2009: 109), Case studies involve in-depth contextual analyzes of matters relating to similar situations in other organizations. We noted earlier that case studies, as a problem-solving technique, are not frequently resorted to in organizations because finding the same type of problem in another comparable setting is difficult due to the reluctance of companies to reveal their problem. Case studies that are qualitative in nature are, however, useful in applying solutions to current problems based on past problem-solving experiences. They are also useful in understanding certain phenomena, and generating further theories for empirical testing.

The choice of this research design is because qualitative research is used to gain a deep understanding of interesting phenomena with informants and can also provide more indepth knowledge that is relevant to the research to be carried out. Researchers try to take data in a reasonable atmosphere without manipulating or engineering the existing situation and or intervene in the existing situation, so that the data obtained will meet the required data validity.

In this study, the author acts as an instrument as well as data collector. As for instruments other than humans that can be used, but their function is only as a supporter and assistant in research.

In terms of data collection, the authors go directly to the field in the community of research subjects. The author's role as the main instrument in the data collection process, the author does it by observing and conducting direct discussions with several parties and 
related elements. While in the field, the author acted as participant observer. That is, researchers observe directly in observation activities in the field. The researcher is part of the group he is studying.

This research was conducted by PT. Commander of Primadona Gemilang (PT. PPG) Surabaya. Researchers chose this location because PT. Panglima Primadona Gemilang is a company engaged in the production and distributor of especially animal feed so that according to the author the location taken is very relevant to the problem that the author wants to examine.

According to Sekaran and Bougie (2009:37) data sources are divided into two, namely:

a. "Such data gathered for research from the actual site of occurrence of events are called primary data". Thus, primary data is actual data originating from the scene or company under study.

b. "Data gathered through such existing sources are called secondary data.

That is, they are data that already exists and do not have to be collected by the researcher". Secondary data is data that already exists and researchers do not need to collect it. For example, through the web, journals, theses, articles, company documentation, government publications, the internet, and so on.

To obtain the data information needed in this study, the authors use the method through field research (Field Research), namely research conducted directly on the object of research. Techniques used include:

a. Interview. This technique is a way to obtain data by conducting direct interviews with leaders or employees so that valid and reliable data can be obtained.

b. Observation. The observation method is a research conducted by looking directly at events in the field and then drawing conclusions through the reality that occurs in the field.

c. Library Studies (Library Research). Research conducted by studying literature or other references related to the subject matter so that it is used as a reference for analysis to solve problems faced by the company.

Data processing is done by using qualitative description analysis techniques. This technique provides a review or explains the data obtained to be clearer in the form of a narrative. The steps of this technique are to reduce the data from the data that the researchers got from the results of interviews, interviews and literature review. The process of data reduction is data reduction through coding and categorization. Coding is an analytical process where the qualitative data that has been collected will be reduced, rearranged, and integrated. The purpose of coding is to help researchers to draw conclusions from the data from interviews, interviews and literature review. After the coding process is complete, the researchers classify the coding that has been done in order to find out the extent to which the meaning or conclusions of the data obtained are in accordance with the objectives of the study. Then, the researcher carried out a categorization process which was the process of organizing, organizing, and classifying coding units. So that the meaning or conclusion that the researcher has obtained with the existing categories will be linked to one another.

After the data reduction process is carried out, the next step is data display. Data display is the presentation of data with charts, diagrams, and even text with the aim of making it easier for researchers to understand the data that has been obtained. Then the last step in the descriptive analysis technique is drawing conclusions. According to Sekaran and Bougie (2009:382-383),

Conclusion drawing is the "final" analytical activity in the process of qualitative data analysis. It is the essence of data analysis; it is at this point where you answer your researcher questions by determining what identified themes stand for, by thinking about explanations for observed patterns and relationships, or by making contrasts and comparisons.

In qualitative research, drawing conclusions is the last activity of analyzing data. In this case, the researcher provides an explanation of the data that has been collected both primary and secondary data and relates it to the problem formulation that the researcher has previously determined or by making a comparison. 
After the data is collected and analyzed, the researcher needs to re-check with the aim of knowing the validity of the data findings from the study. To determine the validity of the data, the examination technique described by Moleong (2004:175-177) is needed as follows:

a. Extended participation. The researcher in qualitative research is the instrument itself. The participation of researchers is very decisive in data collection. This participation is not only carried out in a short time, but requires an extension of the researcher's participation in the research setting. The extension of the researcher's participation will allow an increase in the degree of confidence in the data collected.

b. Observation persistence. Persistence of observation means finding characteristics and elements in a situation that are very relevant to the problem or issue being sought and then focusing on these things in detail. In other words, if extended participation provides scope, persistence of observation provides depth.

\section{RESULTS AND DISCUSSION}

Based on data gathering and analysis about the adoption of COSO and CSA in the internal control system for material inventory of PT. PPG Surabaya can be summarised as follows:

1. Control Environment. The internal control environment for raw material inventory at PT. PPG Surabaya can be explained based on the factors that make up the control environment of PT. PPG Surabaya. The raw material inventory control environment at PT. PPG Surabaya covers all attitudes and employees regarding the importance of inventory control. Which of the factors that affect the internal control environment inventory are:

a. Operations management philosophy and style. Management philosophy is a set of parameters for companies and employees. Philosophy is what should be done and what should not be done by the company. The management philosophy applied to PT. PPG Surabaya is very supportive and creates an adequate control environment.

According to one of the informants, Mrs./Mr. Paharuddin from the personnel department, that:

The management philosophy applied by the manager of PT. PPG Surabaya is the head of PT. PPG Surabaya emphasizes on employees to always comply with the rules made by the company besides that employees must also create good business relationships. In this case, all employees are emphasized to act and be kind to all consumers, suppliers and other parties related to the company.

Management operating style at PT. PPG Surabaya is a director who always emphasizes the principle of kinship. Every employee of PT. PPG Surabaya is considered as part of the big family of PT. PPG Surabaya. And for company employees, they no longer do training but refresh SOPs. The director sets an example of how to be kind to all parts of the company. This family management style makes employees feel at home and happy to work at PT. PPG Surabaya.

The operating style of management reflects the manager's idea of how the company's operations should be carried out. To make employees understand the importance of complying with existing regulations and always creating good relationships with all parts related to the company. Here the director always gives an understanding of the importance of complying with the rules by assuming that all employees in the company are part of the family. So the closeness between parts of the company is maintained and can easily find out problems related to the company so that good internal control can be created.

According to the philosophy and style of operations management at PT. PPG Surabaya seems good enough where management emphasizes the importance of internal inventory control to employees so that it will create an effective control environment.

b. Commitment to Integrity and Ethical Values. It is important for managers to create an organizational culture that emphasizes integrity and ethical values. Ethical or unethical behavior has a major impact on overall internal control. PT. PPG Surabaya has applied integrity and ethical values to its employees. This can be seen from the regulations applied by management in the form of rules that must be implemented. 
According to the informant, Mrs./Mr. (Rachman) from the personnel department, that:

"Integrity and ethical values that exist in PT. PPG Surabaya is the Director of PT. PPG Surabaya upholds honesty in every activity. Honesty in question is a disciplined attitude with high integrity. In addition, every eight o'clock in the morning or before starting work, all employees are gathered to have a morning apple by praying together. Hence, the honesty is one of the ethics that is maintained at PT. PPG Surabaya. Honesty is meant to be honest in business and honest about the quality of the goods made."

PT. PPG Surabaya was built on the foundation of honesty and ethical values because for PT. PPG Surabaya is not only useful for shaping the daily behavior of employees, but also guiding them when carrying out the decision-making process. So if ethical values can be enforced consistently and consequently, the foundation of good governance within the company will be more solid.

c. Audit Committee and Board of Directors. The role of the audit committee is to monitor the company's accounting and financial reporting practices and policies. At PT. PPG Surabaya does not yet have an audit committee. Activities to monitor the effectiveness of accounting policies and procedures related to inventory control are carried out by internal audit. In this case, internal audit carries out the function of checking and assessing efficiency and effectiveness in the fields of finance, accounting, operations, human resources and other activities.

d. Organizational structure. The organizational structure is structured to determine the authority, position, duties, responsibilities and relationships between organizational units contained in the company. The company structure must allow for coordination between all parts to take actions in an effort to achieve company goals.

At PT. PPG Surabaya preparation of organizational structure based on functions in accordance with what the company needs so that it can be seen clearly the division of tasks and authority of each function in the company, so that control can be carried out even better. The organizational structure contained in PT. PPG Surabaya consists of the Owner who under him consists of the General Manager, Administration Section, Accounting Section, Tax Section, Receivable section and Warehouse Section.

e. Assignment of Authority \& Responsibility. Determination of authority and responsibility is the development of the organizational structure, which is broadly manifested in the form of separation of functions. It is important for organizations to have clear job descriptions. Without a clear job description, responsibilities can be thrown away. Separation of functions in the organizational structure at PT. PPG Surabaya has also been held, namely accounting, production and personnel functions.

With the separation of these functions, management at a higher level can assess the parts they lead, whether each employee has performed their duties properly according to their functions. However, in the division of functions, there are still dual positions, namely the function of receiving and storing materials concurrently by the warehouse section. And for the physical inventory count, the company also does not have its own physical counting committee, the physical inventory count is concurrently with the accounting and warehouse functions.

f. Human Resources Policies and Practices. According to the informant, Mrs./Mr. (Rachman) from the administrative section, that:

"Recruitment of employees at PT. PPG Surabaya is handled by the personnel department. If the company needs employees, the personnel department will make job vacancies advertisements in print media by determining certain conditions for the specified job qualifications. After going through the administrative process, then the selection is carried out, namely interviews. After the employees are declared to have passed, they will undergo a training period of 3 months, only after those employees who meet the company's criteria will be appointed as employees or permanent employees of the company."

2. Risk Assessment. The materials used to carry out the production process at PT. PPG Surabaya is sugar cane. So if there is a buildup of raw materials, these raw materials will be very vulnerable to damage, this can cause losses for the company. So to anticipate this, the company conducts weekly stock taking and monthly stock taking. The goal is to find 
out the truth of the records in the books which is one of the functions of the internal control system.

This was clarified by the informant Mrs./Mr. (Amin S.IP.) as a staff at the warehouse, that: "Risk assessment carried out by PT. PPG Surabaya so that the presentation of information on the supply of raw materials is reasonable and timely is good enough. The Director has identified and studied the existing risks, and established the necessary control activities to deal with them. To determine the risk, the company holds a stock taking that checks the correctness and reasonableness of the quantity and service life of each raw material, so that the first goods that enter should be the first to come out, so that the risk of damage can be minimized.

Weekly stock taking is done so that monitoring and assessment of raw materials is more effective and can make it easier when you will do monthly stock taking. Weekly stock taking is carried out by the warehouse department and monthly stock taking is carried out by the accounting department.

In addition to maintaining security from the risk of raw materials PT. PPG Surabaya, the company's management estimates the costs that will be incurred to carry out control measures in a way that before budgeting is carried out, the annual target must be made so that the profits can be known. To maintain security from the risk of theft of goods, PT. PPG Surabaya by installing CCTV at the company. CCTV installation aims to monitor employee performance, company security and control the theft of goods, both from within and from outside."

3. Control Activities. Control activities in PT. PPG Surabaya includes policies and procedures that must be carried out by companies that can ensure the system has not been running effectively. Control activities carried out by PT. PPG Surabaya mostly by the owner, since no clear description of authority in each section. Hence, all staff just doing whatever command from the owner

4. Information and Communication. The information and communication system carried out by PT. PPG Surabaya is quite good. This can be seen from the preparation of clear procedures within the company, including the raw material inventory control procedures that involve several related functions, namely the function of receiving raw materials, purchasing functions, raw material warehouses and accounting, documents and records needed as well as reports generated and recording into accounting records based on source reports attached with complete supporting documents that have been authorized by the respective head of the department. In the following, information and communication systems related to the demand and return system for raw materials will be explained: Warehouse.

a. Information and Communication System for Raw Material Request and Release from

For the demand and release of raw materials from the warehouse, there are two related functions, namely the production function and the warehouse function. While the related accounting records are inventory cards. In requesting and releasing raw materials from the warehouse, the production department requests the warehouse.

b. Information and Communication System for the Return of Raw Materials to the Warehouse

For the return of raw materials to the warehouse the related functions are the production function, the warehouse function and the accounting function. While the accounting records used are inventory cards.

5. Monitoring/Supervision. The monitoring process is usually carried out by the Owner assisted by the General Manager from the head office. Every effort made by the company regarding the implementation of monitoring in relation to the implementation of internal control of raw material inventory by observing directly whether the procedures that affect inventory and payments have been carried out in accordance with the provisions. If there is a loss of raw materials in the warehouse, it is the responsibility of the warehouse department, supervision, and the head of the warehouse will make a report of loss of goods as an accountability report to the General Manager. 
It was clarified by the informant Mrs./Mr. (Titik) as General Manager, that:

"Supervision of existing performance at PT. PPG Surabaya is already good. Performance monitoring is carried out by internal audit. Supervision is carried out such as ensuring whether the company's internal control is good or not, determining the reliability of information and ensuring whether all employees have carried out their responsibilities effectively and have complied with the rules that have been set so that the company's goals can be achieved."

Table 1 - Adoption of CUSO and CSA in PT. PPG Surabaya

\begin{tabular}{|c|c|c|c|}
\hline No. & $\begin{array}{l}\text { Procedure Aspect } \\
\text { Internal control }\end{array}$ & $\begin{array}{l}\text { Level } \\
\text { Control }\end{array}$ & Reason \\
\hline 1 & $\begin{array}{l}\text { Environment } \\
\text { Control of raw } \\
\text { material inventory }\end{array}$ & Strong & $\begin{array}{l}\text { Management operating style on PT. PPG Surabaya is a director who always } \\
\text { emphasizes the principle of kinship. Every employee of PT. PPG Surabaya is } \\
\text { considered as part of the big family of PT. PPG Surabaya. And for company } \\
\text { employees, they no longer do training but refresh SOPs. The director sets an } \\
\text { example of how to be kind to all parts of the company. This family management } \\
\text { style makes employees feel at home and happy to work at PT. PPG Surabaya. }\end{array}$ \\
\hline 2 & Risk Assessment & Strong & $\begin{array}{l}\text { In maintaining security from the risk of raw materials PT. PPG Surabaya, were } \\
\text { depend on the Owner and general manager. The company estimates the costs } \\
\text { that will be incurred to organize control measures in a way before budgeting } \\
\text { done, the annual target is definite made so that the benefits obtained can be } \\
\text { known. To keep safe from the risk of theft of goods is also carried out by PT. } \\
\text { PPG Surabaya by installing CCTV at the company. CCTV installation aims to } \\
\text { monitor employee performance, company security and control the theft of goods, } \\
\text { both from within and from outside. }\end{array}$ \\
\hline 3 & Control Activities & Weak & $\begin{array}{l}\text { Control activities in PT. PPG Surabaya cover the existence of policies and } \\
\text { procedures that must be carried out by the company that can ensure that the } \\
\text { system is running effectively. This proven in the design documents used in the } \\
\text { procedure the purchase and procurement of inventory items has been serially } \\
\text { numbered printed on this is a tool to authorize the implementation transactions } \\
\text { so that by using a printed serial number it is possible to determine accountability } \\
\text { for the implementation of document transactions good and serial numbered print. } \\
\text { However, the control activities carried out in raw material inventory this still } \\
\text { needs to be improved because there are still multiple functions in the reception } \\
\text { and storage. }\end{array}$ \\
\hline 4 & $\begin{array}{l}\text { Information and } \\
\text { Communication }\end{array}$ & Strong & $\begin{array}{l}\text { Information and communication system carried out by PT PPG Surabaya is good } \\
\text { enough. This can be seen from the preparation of clear procedures in the } \\
\text { company, including in the supervisory procedures raw material inventory } \\
\text { involves several related functions, namely the reception function raw materials, } \\
\text { purchasing function, warehouse of raw materials and accounting, documents } \\
\text { and records needed as well as reports produced and recording into accounting } \\
\text { records based on source reports attached with complete supporting documents } \\
\text { that have been authorized by the respective head of the department. }\end{array}$ \\
\hline 5 & $\begin{array}{l}\text { Inventory related } \\
\text { monitoring activities } \\
\text { company raw } \\
\text { materials }\end{array}$ & Strong & $\begin{array}{l}\text { Monitoring is carried out in order to assist management to find out the } \\
\text { ineffectiveness of the implementation of other control elements. PT. PPG } \\
\text { Surabaya conducts material inventory monitoring standard by doing a stock take } \\
\text { which every month to adjust to the development of consumer demand. Where } \\
\text { the purpose of doing this stock taking is to know the truth of the records in the } \\
\text { books which is one of the functions of internal control system. }\end{array}$ \\
\hline
\end{tabular}

The results of research at PT. PPG Surabaya that the internal control system that fully adopts COSO and CSA had not been fully effective, in which the company's management has implemented the concepts and principles of internal control, and there are several procedures that reflect the concept of internal control that adopts COSO. However, in control activities those still need to be improved because there are still multiple functions in the reception and storage department.

Internal control carried out by PT. PPG Surabaya in the raw material inventory system in the form of separation of duties which records the number of incoming and outgoing goods, which is handled by the warehouse section with the section that records the cost of each type of inventory that enters or exits which is handled by the administrative staff of inventory recording. Segregation of duties must also be carried out between the warehouse section and the shipping section, the shipping section is responsible for delivering goods that have been approved by the administration section and the warehouse section.

These findings were not in line with research by Francis (2017) which states that PT Wijaya Baja Indonesia has good internal control in its inventory cycle which is fully adopted 
and implemented the 5 COSO frameworks to inventory activities. Moreover, Hans (2017) in his research at PT Gawih Jaya found that PT. Gawih Jaya already has proper internal control on the inventory cycle. This is evidenced by the existence of 5 COSO frameworks that are applied to all activities related to inventory. The five COSO frameworks that have been running well are: 1 . A control environment that is not only created but also implemented well by every human being of PT. Galih Jaya. 2. Risk assessment which shows that PT. Galih Jaya has minimized risk by implementing existing internal controls. 3. Control activities of PT. Galih Jaya which has implemented 6 categories of physical control in its entire inventory cycle. This is also supported by the use of SAP software which has a very adequate control function. 4. Information and communication PT. Gawih Jaya has used adequate documents for each inventory procedure so that all activities can be recorded, recorded and reported properly because of the SAP software. 5. Supervision of PT. Gawih Jaya which has been going well because it is in accordance with existing policies.

\section{CONCLUSION}

Based on the results of the research in the previous chapter by carrying out the stages of evaluating the inventory cycle internal control accompanied by conducting data analysis based on theories that are relevant to the problems studied at PT. PPG Surabaya, the researchers concluded that the internal control system which fully adopts COSO has not been fully effective, in which the company's management has implemented the concepts and principles of internal control, and there are several procedures that reflect the concept of internal control that adopts COSO. However, in control activities that still need to be improved because there are still multiple functions in the reception and storage department.

Internal control carried out by PT. PPG Surabaya in the raw material inventory system in the form of separation of duties which records the number of incoming and outgoing goods, which is handled by the warehouse section with the section that records the cost of each type of inventory that enters or exits which is handled by the administrative staff of inventory recording. Segregation of duties must also be carried out between the warehouse section and the shipping section, the shipping section is responsible for delivering goods that have been approved by the administration section and the warehouse section. This seem to occur cause of the implementation of the internal control system still depends on one person, namely the owner or company owner.

Based on the results of data analysis obtained through interviews, observations, and interviews at PT. PPG Surabaya, researchers provide input for companies, namely:

1. Raw material planning must be prepared by several relevant departments and communicate effectively so that the implementation of production and planning in the department, especially marketing can be in line and there is no accumulation of raw materials in the warehouse;

2. The company must provide written procedures regarding the maintenance and maintenance of equipment so that the products produced can be maximized and maintain the life of the production equipment;

3. The company must provide written specifications and product quality standards to employees who are directly related to the production process so that the possibility of product rework can be minimized;

4. Create a system based on available technology to assist in accelerating the decision-making process.

Research Limitations. The researcher admits that there are several obstacles or limitations in conducting the research. First, the researcher was not able to get quantitative data (numeric) that could increase the quality of the inventory cycle internal control evaluation examination because the company did not allow or allow it. Second, it takes a long time to be able to get interview with the staff, since it need to give long understanding the risk of interview toward their future in the company, even though permission was already approved by the owner. 


\section{REFERENCES}

1. Agoes, Sukrisno. 2004. Evaluasiing (Pemeriksaan Akuntan) Oleh Kantor Akuntan Publik Jilid II. Jakarta: Fakultas Ekonomi Universitas Indonesia.

2. Anastasia, Diana. Setiawan, Lilis. 2010. Sistem Informasi Akuntansi, Penerbit Andy, Yogyakarta.

3. Arens, Alvin A., Elder, Randal J., dan Beasley, Mark S. 2008. Evaluasiing dan Jasa Assurance Pendekatan Terintegrasi. Terjemahan oleh Herman Wibowo. 2014. Jakarta: Erlangga.

4. Bayangkara, IBK. 2008. Evaluasi pengendalian internal siklus persediaan: Prosedur dan Implementasi. Jakarta: Salemba Empat.

5. Baridwan, Zaki, 2014, Intermediate Accounting, Edisi Kedelapan, Yogyakarta: Penerbit BPFE.

6. Boynton, Wiliam C., Johnson, Raymond N., dan Kell, Walter G. 2001. Modern Evaluasiing Edisi Ketujuh. Terjemahan oleh Yati Sumiharti. 2002.Jakarta: Erlangga.

7. Daft, Richard L. 2006. Management 6th Ed. Terjemahan oleh Edward Tanujaya dan Shirly Tiolina. 2006. Jakarta: Salemba Empat.

8. Darmawi, Herman, 2012, Manajemen Perbankan, Jakarta: Bumi Aksara. Gondodiyoto,

9. Diana, A. dan L. Setiawati, 2011, Sistem Informasi Akuntansi, Yogyakarta: ANDI.

10. Fransiscus, 2017, Sistem Pengendalian Internal terhadap Siklus Persediaan Bahan Baku pada Perusahaan Manufaktur Besi Baja PT Wijaya Prima Baja Indonesia, (repository.wima.ac.id/, diunduh 12 Desember 2017).

11. Gu. 2013 Research and Analysis on Issued Inventory Valuation Methods of Enterprises. International Academic Workshop on Social Science. Jiangxi University of Finance and Economics .Nanchang, China. http://www.atlantis-press.com/

12. Hall, J.A., 2004, Accounting Information System, 2007, Terjemahan oleh Dewi Fitriasari dan Deny Arnos Kwary, 2009, Edisi Empat, Jakarta: Salemba Empat.

13. Haming, Murdifin. dan Nurnajamuddin, Mahfud. 2007. Manajemen Produksi Modern: Operasi Manufaktur dan Jasa. Jakarta: Bumi Aksara.

14. Handayani, Fitri Dwi. 2008. Pemeriksaan Manajemen Terhadap Fungsi Produksi untuk Menilai Tingkat Efisiensi dan Efektifitas Usaha pada Perusahaan Rokok "Lembang Jaya" Malang.

15. Hans, 2017, Evaluasi Pengendalian Internal Siklus Persediaan Barang Jadi pada Perusahaan Distributor Rokok PT Gawih Jaya, (repository.wima.ac.id/ diunduh 12 Desember 2017).

16. Hery. 2011. Auditing I, Dasar-dasar Pemeriksaan Auditing, Penerbit Kencana, Jakarta.

17. Hery. 2012. Akuntansi Keuangan Menengah 1, Edisi 1, Cetakan Pertama, PT. Bumi Aksara, Jakarta.

18. Hum, M Mahmuzar, 2010, Sistem Pemerintahan Indonesia, Bandung: penerbit Nusa Media.

19. Ikatan Akuntansi Indonesia, 2009, Standar Akuntansi Keuangan, Jakarta: penerbit Salemba Empat.

20. Ikhsan, Arfan, 2010, Pengantar Praktis Akuntansi, Edisi Pertama, Yogyakarta: Penerbit Graha IImu.

21. Jogiyanto, 2005, Analisis dan Desain (Sistem Informasi : pendekatan terstuktur teori dan praktik aplikasi bisnis), Yogyakarta: ANDI.

22. Joseph, Gilbert W. dan Engle, Terry J. 2005. The Use of Control Self- Assessment by Independent Evaluasiors. The CPA Journal.

23. Kieso, Donald, E, Weigandt dan J, Warfield. 2012. Intermediate Accounting. Erlangga, Jakarta.

24. Libby, Robert, Patricia Libby, Daniel G Short, 2008, Akuntansi Keuangan, Edisi Pertama, Yogyakarta: Penerbit Andi.

25. Manurung, Elvy Maria, 2011, Akuntansi Dasar, Jakarta: Penerbit Erlangga.

26. Marshall, Romney B. dan Paul John Steinbart, 2010. Accounting Information System. Edisi Ke Sembilan. Salemba Empat, Jakarta. 
27. Moeller, Robert R. 2009. Brink's Modern Internal Evaluasiing: A Common Body of Knowledge. New Jersey: John Wiley \& Sons, Inc.

28. Moleong, Lexy J. 2004. Metode Penelitian Kualitatif. Bandung: Remaja Rosdakarya.

29. Mulyadi., 2016, Sistem Akuntansi, Edisi Keempat ,Jakarta: Salemba Empat.

30. Mujilan,A., 2012, Sistem Informasi Akuntansi, Edisi Pertama,Madiun: WIMA Pers.

31. Nafarin, M, 2010, Akuntansi Pendekatan Siklus dan Pajak Untuk Perusahaan Industri dan Dagang, Jakarta: Penerbit Ghalia Indonesia.

32. Nyoman, Wenny. 2010. Evaluasi pengendalian internal siklus persediaan atas Fungsi Produksi pada PT Multi Plasindo Indah. Skripsi tidak diterbitkan. Jakarta: Fakultas Ekonomi dan Bisnis Universitas Bina Nusantara.

33. Prawirosentono, Suyadi. 2001. Manajemen Operasi: Analisis dan Studi Kasus. Jakarta: Bumi Aksara.

34. Rama, D. V., dan F. L. Jones, 2008, Sistem Informasi Akuntansi (Accounting Information System), terjemahan oleh M. Slamet Wibowo, Jakarta: Salemba Empat, Buku 1.

35. 2009, Sistem Informasi Akuntansi (Accounting Information System), terjemahan oleh M. Slamet Wibowo, Jakarta: Salemba Empat, Buku 2.

36. Reeve, James, Warren, Jonathan, Wahyuni, Suprianto, Jusuf, dan Djakman. 2013. Pengantar Akuntansi. Salemba Empat, Jakarta.

37. Romney, M.B., dan P.J. Steinbart, 2015, Sistem Informasi Akuntansi, Terjemahan oleh Kikin Sakinah NurSafira dan Novita Puspasari, 2015, Edisi Ke Tiga Belas, Jakarta: Salemba Empat.

38. Rudianto, 2012, Pengantar Akuntansi, Jakarta: Penerbit Erlangga.

39. Samuelson, Paul A. dan Nordhaus, William D. 2005. Economics (Seventeenth Edition). New York: McGraw-Hill Irwin.

40. Santoso, Iman. 2010. Akuntansi Keuangan Menengah. Pt. Rafika Aditama, Bandung.

41. Sanyoto. 2007. Audit Sistem Informasi, Edisi Revisi, Penerbit Mitra Wacana edia, Jakarta

42. Sekaran, Uma dan Bougie, Roger. 2009. Research Methods for Business: A Skill Building Approach (5th ed). United Kingdom: John Wiley \& Sons Ltd.

43. Soemarso, SR, 2010, Akuntansi Suatu Pengantar, Edisi Keempat, Jakarta: Penerbit Rineka Cipta.

44. Sutabri, Tata, 2010, Sistem Informasi Akuntansi, Yogyakarta: Penerbit Andi. Sumarsan,

45. Thomas. 2011. Akuntansi Dasar dan Aplikasi dalam Bisnis. Jakarta: Indeks.

46. Tunggal, Amin Widjaja. 1992. Evaluasi pengendalian internal Suatu Pengantar. Jakarta: Rineka Cipta.

47. 2000. Evaluasi pengendalian internal siklus persediaan Kontemporer Edisi Revisi. Harvarindo.

48. Winwin Yadiati, 2010, Teori Akuntansi : Suatu Pengantar, Jakarta: Penerbit PT. Kencana. 